\title{
GENDER IDEOLOGY IN THE DIARY OF ADAM AND EVE BY MARK TWAIN
}

\author{
Paramita Ayuningtyas \\ Jurusan Sastra Inggris, Fakultas Bahasa dan Budaya, Bina Nusantara University \\ Jln. Kemanggisan Ilir III No. 45, Palmerah, Jakarta Barat 11480
}

\begin{abstract}
This article aims to show that behind the new version of Genesis by Mark Twain in his novel The Diary of Adam and Eve, there are some patriarchal principles that appear in it. It can be seen from the characterizations of Adam and Eve. By using some concepts from feminism and also focusing on the context of the novel, the analysis shows that patriarchal stereotypes about gender are applied in constructing the characters of Adam and Eve. Not only the content, but the form of the diary is also analyzed with the same method, and the same result is found. Therefore, it can be concluded that in spite of his progressiveness, Mark Twain still held patriarchal values in re-interpreting the tale of human creation.
\end{abstract}

Keywords: gender, stereotypes, feminism, femininity, masculinity

\begin{abstract}
ABSTRAK
Artikel menjelaskan pembelajaran yang ada di belakang Kitab Kejadian, yang ditulis oleh Mark Twain dalam novel yang berjudul The Diary of Adam and Eve. Novel tersebut menunjukkan adanya prinsip patriarki yang terlihat dari karakter Adam dan Eva. Dengan menggunakan konsep Feminisme dan berfokus pada konteks novel akan terlihat penerapan strereotip patriarki yang terkait dengan gender di dalam penokohan Adam dan Hawa. Tidak hanya konten, tetapi bentuk diary juga dianalisis dengan metode yang sama dan menghasilkan hasil yang sama pula. Disimpulkan, di samping progessiveness, mark Twain juga masih memegang prinsip patriarki dalam menginterpretasi kembali cerita ciptaan manusia.
\end{abstract}

Kata kunci: gender, stereotip, feminisme, feminimiti, maskuliniti 


\section{INTRODUCTION}

Probably Genesis is a story that can never be replaced even though ages come and go and canonic religions have been substituted by other 'religions'. Besides revealing the creation of Adam and Eve. Genesis also tells about the fall of men caused by Satan who changes himself into a snake. The snake successfully seduces Eve to eat the forbidden fruit from 'The Tree of Knowledge of Good and Evil'. Inspired from that story, Mark Twain wrote The Diary of Adam and Eve, or known as Siti Hawa in Islam. In The Diary of Adam and Eve, readers are taken to see the tale of creation through Adam and Eve's points of view embodied in a form of diary. This re-interpretation of Genesis is the most engaging aspect in this novel and triggers some questions as well: how did Mark Twain represent Adam and Eve?, and What kind of gender ideology that can be decoded from the representation?

\section{METHODS}

By conducting a study on characterizations and relating it with the context of the novel, the writer is going to answer those above research questions. The primary data that will be used is Extract from Adam's Diary and Eve's Diary. Actually, The Diary of Adam and Eve published by Hesperus is a compilation that also includes other parts, such as That Day in Eden and Adam's Soliloquy. However, I will only focus on Extract from Adam's Diary and Eve's Diary because both were published in 1906, while other parts were published years after.

\section{RESULTS AND DISCUSSIONS}

\section{Eve's Characterization}

In traditional discourse of Western Christianity, the figure of Eve has become an epitome of a sinful woman (Budianta, 1998: 6). Eve, who ate the forbidden fruit, is blamed for the fall of human kinds. How is Eve, often labeled as seductress, portrayed by Mark Twain? From her diary, Eve is depicted as a thinker. It can be observed from her philosophical and critical writings. One of the examples is from her first inscription when she's still one-day old:

For I feel like an experiment, I feel exactly like an experiment; it would be impossible for a person to feel more like an experiment than I do, and so I am coming to feel convinced that that is what I am - an experiment; just an experiment, and nothing more.

Then if I am an experiment, am I the whole of it? No, I think not. I think the rest of it is a part of it. I am the main part of it, but I think the rest of it has its share in the matter. (Twain, 2002: 21).

The quotation above shows how Eve really contemplates on where she comes from and what is the purpose of her creation. She tries to understand her own existence.

Eve is also described as an intelligent human. Eve's mind potential is emphasized by Twain through Eve's actions. Eve likes to name creatures or things that she has just found. This cleverness of hers is also noted in Adam's diary: The new creature names everything that comes along ... (5). Naming does not necessarily mean giving labels to things, yet behind the process there is a performance of power and control (Prabasmoro, 2006: 273). By naming new things, Eve implicitly 
takes control in forming their views on the world. Eve's smartness is also seen in her grammar knowledge. When discovering that Adam is a man, she tries to find a precise pronoun for Adam: nominative, he; dative, him; positive, his'n (25). She soon learns that Adam is a human like her. With her intelligence, Twain portrayed Eve as a woman far from the 'silenced' position because she likes to talk much: ... for I love to talk; I talk all day, and in my sleep, too ... (Twain: 2002). She also discovers fire, an important element in human's life.

Eve's characterization by Twain shakes the gender construction of patriarchal society about femininity traits. In traditional society with patriarchal norms, activity is considered as a masculine characteristic, supposedly owned by men. However, in The Diary of Adam and Eve, this characteristic belongs to Eve, through her act of naming and expressing what is on her mind. In term of intellectuality, Eve's characterization tears down the myth that women are 'unable to work requiring muscular or intellectual development'. This effort to pull down the patriarchal gender construction signifies that Twain realized that femininity and masculinity are socially constructed and because of that, there is always a possibility to reconstruct and deconstruct it. In this case, it is done through woman representation in fictions.

Even so, further analysis shows that the depiction of Eve is in an ambiguous area. In Eve's characterization, Twain also highlighted some qualities that 'naturally' belong to women. For instance, Eve admits that she loves beauty: ... but I already begin to realise that the core and centre of my nature is love of the beautiful (22). The use of words 'core', 'centre' and 'nature' strengthens essentialism concepts that woman have several natural traits since the day that they were born. Eve's love to beauty is considered as a part of nature in The Diary of Adam and Eve, and it is in contrast with Adam's pragmatic attitude.

The concept of essentialism also appears in Eve's relationship with Adam. Eve states that she cannot live by herself because 'I was made for it' (35); therefore, she always wants to be with Adam. Eve, who at first thinks philosophically about her existence, now positions herself only as a creature to accompany Adam. Prabasmoro (2006: 306) wrote that women are often constructed as creatures desperately longing for love. It can be seen from how Eve keeps trying to get close to Adam just because she realizes that she was made for it. She is in love with Adam since Adam looks so masculine, and she does not care if Adam treats him badly: At bottom he is good, and I love him for that. If he should beat me and abuse me, I should go on loving him (39). She feels that she cannot live without Adam. So, no matter what happens (even though it tortures her), she will keep loving Adam. For Eve, her life without Adam 'would not be life'. This can be read as: women's existence means nothing without men's existence. This condition can also be observed in 'Eve's Diary' that has to be interrupted by one entry from Adam's diary that talks about Eve's body

Eve's desire to be with Adam all the time leads to her effort to be approved by the first man. When realizing that she just discovers fire, the first thing that flashes in her mind is she has to tell Adam to gain his admiration: ... [I] was going to run and find him and tell him about it, thinking to raise myself in his esteem ... (30). A week after her creation, Eve's craving to be respected by Adam is already strong: ... and I study to be useful to him in every way I can, so as to increase his regard (25). It indicates that Eve feels inferior in front of Adam so she needs to gain respect from him.

Another ambiguity can also be found in the naming act done by Eve. Even though she looks active in it, this naming process actually has another purpose, which is to avoid Adam from getting embarrassed (or for men’s sake). It can be concluded from this next passage:

He can't think of a rational name to save him, but I do not let him see that I am aware of his defect. Whenever a new creature comes along I name it before he has time to expose himself by an awkward silence. In this way I have saved him many embarrassments (25). 
What Eve thinks about is to save Adam from embarrassment. Her activity is still dedicated to Adam. Power relation still takes a part in Adam and Eve's relationship, and it can be seen in the way she thinks and in how she should act in front of Adam.

The stereotype that women are emotional can be witnessed in Eve's diary. In her writings, she expresses her feelings much. Sentences that show her emotion, such as 'I am happy', 'I am content' or 'I tried to hide my disappointment' often appear. The binary opposition of controlled/emotional is used in constructing Eve as a character. The plot then reveals that Eve's caring personality leads to the fall of men. Compared to Adam who acts carefully towards animals, Eve tries to be as friendly as possible to animals, including snakes ('She has taken up with a snake now'). Consequently, Eve's closeness with the snake, which is Satan's disguise, causes her to eat the forbidden fruit. In other words, women's loving attitude will lead to something negative and even destructive.

\section{Adam's Characterization}

As the first human, Adam is used to living alone, so when he meets Eve who keeps following her, Adam feels annoyed: It is always hanging around and following me about. I don't like this; I am not used to company (5). He also thinks that the pronoun 'we' that Eve uses to refer to both of them is irritating. Eve desires to be with Adam, but Adam doesn't really care about her existence. He even tries to avoid Eve. This characteristic of Adam supports the masculinity of him, which is independence (Chafetz, ibid.).

From Adam's diary that tends to be descriptive, it can be concluded that he depends on his sight more than his emotion. Next quotations are from Adam's diary:

Cloudy today, wind in the east (5).

Good deal of fog in the morning (6).

If we compare it with Eve's writings (that are full of emotion), Adam mostly writes about what he witnesses. He rarely shows his emotion, even in his personal diary. As told in the analysis of Eve's characterization, the binary opposition of controlled/emotional still holds a role in their characterizations.

Adam is described as a practical man - a character labeled as masculine. He judges things in paradise based on their usefulness. In Eve's eyes, Adam only thinks about the usage of things and forgets about beauty: He would ask what it was good for ... (30). Again, Adam's character is in contrast with Eve's, who 'naturally' loves beauty. What Eve does every day is admiring the prettiness of paradise, while Adam ponders on how to build a shelter from rain. Different from Eve who uses her sight only for the sake of visual joy, Adam uses his to look for valuable things. That difference walks along with the binary opposition of culture/nature that puts men as cultured human beings. In this novel, Adam who manages objects around him shows this 'cultured' trait.

Different from Eve, it takes longer time for Adam to realize that Eve is also a human. At first, he only calls Eve as 'creature' or 'it', and only when Eve tells him, Adam starts to use pronoun 'she' to refer to her. Here, it can be seen that Adam is portrayed not as a smart creature. Another example that shows Adam's stupidity is when he just notices that Cain (and also Abel) is a boy ten years after he's born. He does not even know where Cain comes from: We have named it Cain. She caught it while I was up-country trapping on the north shore of the Eerie (12, underlined by me). Adam speculates that Cain is an animal captured by Eve. He does not even realize that Cain is his and Eve's child. In other words, Adam does not notice the reproductive function of his body.

Adam's characterization tends to be stereotypical with his masculine traits. However, his lack of intellectuality reduces the image of ideal man of him. Besides that, his ignorance of his sexual 
potential creates the depiction that Adam is not sexually aggressive. Nevertheless, this 'un-masculine' side of Adam does not lead to something negative; in fact, it makes him look more innocent. The plot also still shows that Adam is not blamed even though he has eaten the fruit. He believes that eating the apple is against the principle. It can be said that Adam still has the consciousness to differ between the right and the wrong.

\section{Gender Ideology}

After analyzing the image of Adam and Eve, next I am going to study further about gender ideology behind The Diary of Adam and Eve by seeing the context when it was written. Through Eve, it can be seen how Twain made an effort to break the gender boundary by giving some 'masculine' traits to her. She is depicted as a woman who has the brain and the voice. However, it does not mean that this new interpretation is clean from patriarchal values that reduce women with feminine attributes (that are considered inferior). All of Eve's potentials are used for Adam's sake. She also tries to gain respect from Adam, which directly means she considers Adam as someone superior. I read this as the representation of women whose existence needs an approval from men. Compared with Eve's ambiguous and complex characterization, Adam looks stereotypically masculine from his independent, pragmatic and cold attitude. The Diary of Adam and Eve has given a new version of the figures of Adam and Eve, but Twain's description about the two characters is still not free from patriarchal values that put men on the top of the hierarchy. It is related with the social order when the novel was written.

As written by Budianta, literature also constructs, deconstructs and reconstructs ideology (Budianta, 1998: 8). To paraphrase, a work of literature cannot be taken from its social context. In sociology of literature, sometimes an author (consciously or not) cannot be independent from the values of society in which he/she lives. Based on that statement, I am going to see how social context takes a part in constructing the characters of Adam and Eve.

Twain started writing Extract from Adam's Diary in 1893 and Eve's Diary in 1903. During the era, the conservative Victorian values still existed in English society and in American society as well, although in different levels. Even though in early $20^{\text {th }}$ century women were already allowed to go to college and to work outside, gender discrimination still could be found in society. Women (and also children) had to work for twelve hours in factories with a bad condition. In law, rules made by men still placed women in the inferior position. Women were allowed to vote in 1920, years and years after the independence of America. This gender injustice could exist because of patriarchal norms that consider men more competent than women in every aspect of life.

In traditional societies, men are the breadwinners, while women take care of the house and the children. This role division is based on the popular opinion that men are more active and stronger so that they can manage the public life, while women with all of their weaknesses are spatially limited in their domestic world. This division also appears in The Diary of Adam and Eve, especially when Adam and Eve fall from paradise. As a man, Adam does his task as a breadwinner by hunting. Eve who confesses as Adam's wife (even though Adam never says that he is Eve's husband) does her domestic chores, to babysit Cain and Abel. In textual level, the world of Adam and Eve should have been clean from patriarchal-minded society, yet this sex-based role division is already there. In other words, Twain still believed that as something natural and it does not need any reconstruction or deconstruction.

Besides the content, the form of the diary can also be analyzed to find the patriarchal gender ideology behind it. In Adam's diary, there are four passages about the downfall of humankind from paradise, including the event when Eve eats the fruit. It is when they finally realize their nudity and start to feel awkward in front of each other: 
She came curtained in boughs and bunches of leaves, and when I asked her what she meant by such nonsense, and snatched them away and threw them down, she tittered and blushed ... she said I would soon know how it was myself (11).

However, in Eve's diary, Twain inserted only one passage about the fall, which is when the snake teases Eve to taste the fruit. After her writing about her desire to be with Adam, Eve's diary immediately moves to 'after the fall' parts. Eve isn't given the chance to deliver her own version about the fall. The readers cannot see this monumental event from Eve's point of view because this event is only shaped and delivered by Adam's writings. If we see the context when the novel was being written, women in USA still did not acquire the right to voice their opinions on political issues (or issues related to power). Twain did not give the chance and the voice to Eve to tell the readers about what actually happens through her eyes. Yet Twain gave the right to Satan to talk in 'That Day in Eden (passage from Satan's Diary) which tells about how Satan tries to tease Eve.

\section{CONCLUSIONS}

Mark Twain has been dubbed as a progressive author in his era due to his bravery in touching racial issues in The Adventures of Huckleberry Finn (1884). This progressive thought 'tries' to appear too in his interpretation of Adam and Eve's tales. Nevertheless, it does not mean Twain can be totally boundless from the social construction about gender relationships. The characterization of Eve still obeys the essentialism concept that views femininity as a part of nature, and the characterization of Adam is still traditionally masculine. Then, the suppression of women's voice and sex-based role division still can be seen in the text. The patriarchal gender ideology that treats men as the centre of the society still appears in Twain's reinterpretation. Even though the ending of Adam and Eve's diary suggests that both of them (men and women) can live happily ever after, the analysis shows that the effort to reach the harmonious life is still corrupted by gender bias and injustice.

\section{REFERENCES}

Budianta, M. (1998). Sastra dan Ideologi Gender, Horison Vol XXXII/4.

Prabasmoro, A P. (2006). Kajian Budaya Feminis: Tubuh, Sastra dan Budaya Pop. Yogyakarta: Jala Sutra.

Twain, M. (2002). The Diary of Adam and Eve. London: Hesperus. 